\title{
Microbial community diversity analysis of Panax ginseng rhizosphere and non-rhizosphere soil using randomly amplified polymorphic DNA method
}

\author{
Yong Li, Yixin Ying, Dongyue Zhao, Wanlong Ding* \\ Institute of Medicinal Plant Development, Chinese Academy of Medical Sciences and Peking Union Medical College, Beijing, China \\ Email: ${ }^{*}$ wlding@implad.ac.cn
}

Received 17 January 2012; revised 27 February 2012; accepted 6 April 2012

\begin{abstract}
DNA sequence diversities of soil microbial communities in rhizosphere and non-rhizosphere of 1 - 6 years Panax ginseng were evaluated by random amplified polymorphic DNA (RAPD). Total genomic DNA of soil samples were amplified by twenty-four out of two hundred random primers. The products were separated in agarose gel, and 359 and 181 reliable fragments were generated, of which, 324 and 123 were polymorphic. The gene diversity index, Shannon's information index, and similarity coefficient were calculated, and results showed that, diversity of soil microbial community at DNA level was present. Furthermore, with the increasing of $P$. ginseng growing at one site, deference on soil microbial community DNA sequence between rhizosphere and non-rhizosphere tend to be more and more significant. In addition, RAPD technique was proved to be an effective tool to assess the diversity of soil microbial communities. From results we deduced that, the ecological function that performed by soil microbes may changed following the change of microbial community in rhizospheric and non-rhizospheric soils, and finally broke the balance of soil nutrition and energy cycle, soil spatial structure, microbial ecology etc.
\end{abstract}

Keywords: P. ginseng; Microbial Community; Genetic Diversity; Rhizosphere Soil

\section{INTRODUCTION}

Ginseng (Panax ginseng C. A. Mey.) distributed mainly in Changbai Mountain, Northeast of China, and which has been used as a traditional Chinese herbal medicine since ancient times [1]. In natural environment, ginseng was growing wildly, and has almost no disease happened. In the last century, with the fundament of ginse-

"Corresponding author. nosides have significant effect against cancers of human, requirement on it increased rapidly. And which accelerated the annihilation of wild ginseng. Now, wild ginseng was substituted by semi-wild and cultivated ginseng in the market. However, replantation of ginseng usually failed for abnormal grow, severe diseases etc., and in general, more than 30 to 40 years rotation was needed to replant successfully [2]. The following factors were suggested contribute to this problem, which including soil physicochemical characteristics deterioration, nutrient absence, severe diseases, soil microbial community unbalance and autotoxicity [3]. Many trials on fertilized application and soil sterilization have been done, but the final results was not satisfied $[3,4]$.

Soil microorganism is one of the most important parts of soil ecosystem, and which is widely recognized as an integrative component of soil quality for their crucial involvement in many ecosystem processes. Soil microorganisms are of fundamental importance in energy and matter cycle, soil structure, soil micro-ecology balance, etc. Soil microbial communities can indirectly reflect the health status of soil, and study soil microbial communities have important significance to illustrate the mechanism of replantation obstacle. The release of root exudates, which influenced by plant species, plant age and environment factors, creates a unique and attractive environment for microbial growth and activity $[5,6]$. Unfortunately, the importance of rhizosphere microbial diversity is almost unknown. More recently, there is an increasing interest in the analysis of soil microbial community structure $[7,8]$. Among different methods, Random Amplified Polymorphic DNA (RAPD), has been widely used in species classification and phylogenetic analysis [9], species identification [10], and genetic analysis of populations [11]. As the characteristic of quick, simple and inexpensive, RAPD has become one of the most popular DNA-based methods for soil microbial community analysis $[12,13]$.

In recent years, autoxic trail of ginseng was carried out 
in our laboratory, and we found methanol extract of rhizosphere soil and root exudates of $P$. ginseng have significant autotoxic activity $[14,15]$. Also, we found that, part of chemicals in the extract have allelopathy on pathogens happened on $P$. ginseng. So, we want to know whether microbial community in rhizosphere and nonrhizosphere soil was influenced by it. In this paper, RAPD was applied to study microbial community diversity at DNA level. The aim of the present study was to investigate the diversity of soil microbial community at rhizosphere and non-rhizosphere region of $P$. ginseng. Through investigate the soil microbial communities by RAPD, we expected to better understand the importance of soil micro-ecology balance and the developing mechanisms of ginseng replantation problem, and select feasible strategies to improve soil function and quality for further cultivation of $P$. ginseng.

\section{MATERIALS AND METHODS}

\subsection{Soil Sample Collection}

In total, thirty 1 to 6 years $P$. ginseng Rhizosphere and non-rhizosphere soils were sampled in field by poly-sites sampling method from Huangni village (North latitude: $42^{\circ} 31^{\prime} 54.2^{\prime \prime}$ East longitude: $\left.127^{\circ} 15^{\prime} 45.8^{\prime \prime}\right)$ and Dafang village (North latitude: $42^{\circ} 26^{\prime} 03.2^{\prime \prime}$ East longitude: $\left.127^{\circ} 20^{\prime} 00.1^{\prime \prime}\right)$ in Jilin Province of China (Figure 1, Table
1). For each rhizosphere soil sample, 5 to 8 P. ginseng roots growing at the same field were pulled up, and soil tightly adhered on the surface of root was collected. Non-rhizosphere soil samples were collected from the same depth as rhizosphere soil. All soils were put in polyethylene bags and stored at $-20^{\circ} \mathrm{C}$ until DNA extraction.

\subsection{Extraction and Purification of Genomic DNA}

Before DNA extraction, each soil sample were mixed sufficiently, and sieved (two millimeter diameter) to eliminate fibres, impurity, etc. Total microbial genomic DNA were extracted and purified by E.Z.N.A. ${ }^{\mathrm{TM}}$ soil DNA kit (Omega Bio-tek Inc.) according to the protocol. Extracted DNA were tested by $1 \%$ agarose gel electrophoresis, and stored at $-20^{\circ} \mathrm{C}$. DNA templates diluted to $10 \mathrm{ng} / \mu 1$ were used for PCR amplification.

\subsection{Random Amplified Polymorphic DNA Analysis}

After primary screen, twenty four RAPD primers (supplied by Shanghai Sango Co. Ltd.) could amplify clearly polymorphic bands were selected from two hundred primers, and then were used to amplify soil microbial DNA in the experiment (Table 2).

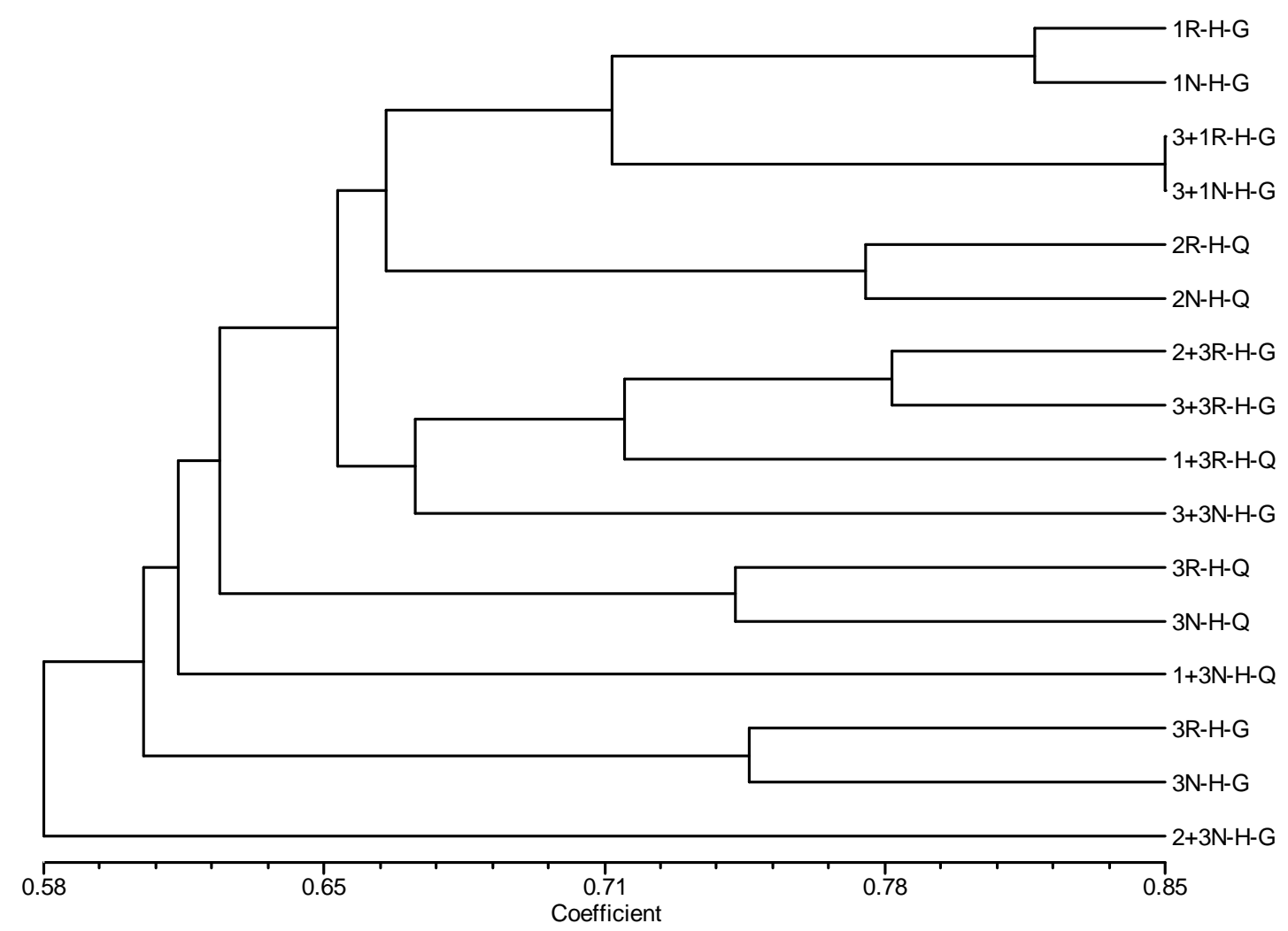

Figure 1. Dendrogram of rhizosphere and non-rhizosphere soils of P. ginseng from Huangni village. 
Table 1. Soil samples collected for genetic diversity analysis of microbial communities.

\begin{tabular}{|c|c|c|}
\hline Symbols & Origin & Description of soil samples \\
\hline 1R-H-G & Huangni & Rhizosphere soil of one-year $P$. ginseng \\
\hline $1 \mathrm{~N}-\mathrm{H}-\mathrm{G}$ & & Non-rhizosphere soil of one-year P. ginseng \\
\hline 3R-H-G & & Rhizosphere soil of three-year P. ginseng \\
\hline $3 \mathrm{~N}-\mathrm{H}-\mathrm{G}$ & & Non-rhizosphere soil of three-year $P$. ginseng \\
\hline $3+1 \mathrm{R}-\mathrm{H}-\mathrm{G}$ & & Rhizosphere soil of four-year P. ginseng \\
\hline $3+1 \mathrm{~N}-\mathrm{H}-\mathrm{G}$ & & Non-rhizosphere soil of four-year $P$. ginseng \\
\hline $2+3 R-H-G$ & & Rhizosphere soil of five-year $P$. ginseng \\
\hline $2+3 \mathrm{~N}-\mathrm{H}-\mathrm{G}$ & & Non-rhizosphere soil of five-year $P$. ginseng \\
\hline $3+3 R-H-G$ & & Rhizosphere soil of six-year $P$. ginseng \\
\hline $3+3 \mathrm{~N}-\mathrm{H}-\mathrm{G}$ & & Non-rhizosphere soil of six-year P. ginseng \\
\hline 3R-H-Q & & Rhizosphere soil of three-year P. quinquefolium \\
\hline $3 \mathrm{~N}-\mathrm{H}-\mathrm{Q}$ & & Non-rhizosphere soil of three-year $P$. quinquefolium \\
\hline 2R-H-Q & & Rhizosphere soil of two-year P. quinquefolium \\
\hline 2N-H-Q & & Non-rhizosphere soil of two-year P. quinquefolium \\
\hline $1+3 \mathrm{R}-\mathrm{H}-\mathrm{Q}$ & & Rhizosphere soil of four-year P. quinquefolium \\
\hline $1+3 \mathrm{~N}-\mathrm{H}-\mathrm{Q}$ & & Non-rhizosphere soil of four-year P. quinquefolium \\
\hline 1R-D-G & Dafang & Rhizosphere soil of one-year $P$. ginseng \\
\hline $1 \mathrm{~N}-\mathrm{D}-\mathrm{G}$ & & Non-rhizosphere soil of one-year P. ginseng \\
\hline 2R-D-G & & Rhizosphere soil of two-year $P$. ginseng \\
\hline $2 \mathrm{~N}-\mathrm{D}-\mathrm{G}$ & & Non-rhizosphere soil of two-year $P$. ginseng \\
\hline 3R-D-G & & Rhizosphere soil of three-year $P$. ginseng \\
\hline $3 N-D-G$ & & Non-rhizosphere soil of three-year $P$. ginseng \\
\hline $2+2 R-D-G$ & & Rhizosphere soil of four-year $P$. ginseng \\
\hline $2+2 \mathrm{~N}-\mathrm{D}-\mathrm{G}$ & & Non-rhizosphere soil of four-year $P$. ginseng \\
\hline $3+2 R-D-G$ & & Rhizosphere soil of five-year $P$. ginseng \\
\hline $3+2 \mathrm{~N}-\mathrm{D}-\mathrm{G}$ & & Non-rhizosphere soil of five-year $P$. ginseng \\
\hline $3+3 R-D-G$ & & Rhizosphere soil of six-year P. ginseng \\
\hline $3+3 N-D-G$ & & Non-rhizosphere soil of six-year P. ginseng \\
\hline $1+2 \mathrm{R}-\mathrm{D}-\mathrm{Q}$ & & Rhizosphere soil of three-year P. quinquefolium \\
\hline $1+2 \mathrm{~N}-\mathrm{D}-\mathrm{Q}$ & & Non-rhizospher soil of three-year P. quinquefolium \\
\hline
\end{tabular}

Note: " $\mathrm{M}+\mathrm{N}$ " indicates grows at site $\mathrm{A}$ for $\mathrm{M}$ years and then transplanted to site $\mathrm{B}$ and grows for $\mathrm{N}$ years. "R" indicates rhizosphere soil; "N" indicates non-rhizosphere soil; "H" indicates soils sampled from Huangni; "D" indicates soils sampled from Dafang; "G" indicates soils of P. ginseng; "Q" indicates soils of P. quinquefolium.

Table 2. RAPD primers used for genetic diversity analysis.

\begin{tabular}{cccccc}
\hline Code & Sequence & $\%$ GC & Code & Sequence & $\%$ GC \\
\hline OPH08 & 5'-GAAACACCCC-3' & 60 & OPR11 & 5'-GTAGCCGTCT-3' & 60 \\
OPH10 & 5'-CCTACGTCAG-3' & 60 & OPR14 & 5'-CAGGATTCCC-3' & 60 \\
OPH11 & 5'-CTTCCGCAGT-3' & 60 & OPR16 & 5'-CTCTGCGCGT-3' & 70 \\
OPI04 & 5'-CCGCCTAGTC-3' & 70 & OPR17 & 5'-CCGTACGTAG-3' & 60 \\
OPJ01 & 5'-CCCGGCATAA-3' & 60 & OPR19 & 5'-CCTCCTCATC-3' & 60 \\
OPJ04 & 5'-CCGAACACGG-3' & 70 & OPS04 & 5'-CACCCCCTTG-3' & 70 \\
OPJ07 & 5'-CCTCTCGACA-3' & 60 & OPS06 & 5'-GATACCTCGG-3' & 60 \\
OPJ08 & 5'-CATACCGTGG-3' & 60 & OPS10 & 5'-ACCGTTCCAG-3' & 60 \\
OPR07 & 5'-ACTGGCCTGA-3' & 60 & OPT16 & 5'-GGTGAACGCT-3' & 60 \\
OPR08 & 5'-CCCGTTGCCT-3' & 70 & OPT17 & 5'-CCAACGTCGT-3' & 60 \\
OPR09 & 5'-TGAGCACGAG-3' & 60 & OPT18 & 5'-GATGCCAGAC-3' & 60 \\
OPR10 & 5'-CCATTCCCCA-3' & 60 & OPT19 & 5'-GTCCGTATGG-3' & 60 \\
\hline
\end{tabular}


The optimized PCR volume was $25 \mu$, including $1 \mu 1$ DNA template $(10 \mathrm{ng} / \mu \mathrm{l}), 2 \mu \mathrm{l}$ primer $(10 \mu \mathrm{mol} / \mathrm{L}$, Sangon Biotechnology Company Ltd., Shanghai), $1.5 \mu \mathrm{l}$ dNTP $(2.5 \mu \mathrm{mol} / \mathrm{L}$, HT Biotech Ltd., Beijing), $2.5 \mu \mathrm{l} 10$ $\times$ PCR Buffer $[100 \mathrm{mmol} / \mathrm{L}$ Tris-HCl $(\mathrm{pH} 8), 500 \mathrm{mmol} / \mathrm{L}$ $\mathrm{KCl}, 15 \mathrm{mmol} / \mathrm{L} \mathrm{MgCl} 2]$, and $0.8 \mu \mathrm{Taq}$ polymerase $(2.5$ $\mathrm{U} / \mu \mathrm{l}$, HT Biotech Ltd., Beijing).

Amplification was performed in a Tgradient 96 thermocycler (Biometra) with the following procedure: an initial denaturation at $94^{\circ} \mathrm{C}$ for $40 \mathrm{~s}$, followed by 45 cycles of denaturation at $94^{\circ} \mathrm{C}$ for $20 \mathrm{~s}$, annealing at $35^{\circ} \mathrm{C}$ for 1 min, extension at $72^{\circ} \mathrm{C}$ for $1 \mathrm{~min}$, and a final extension at $72^{\circ} \mathrm{C}$ for $5 \mathrm{~min}$. PCR products were mixed up with $2 \mu \mathrm{l}$ formamide buffer ( $98 \%$ formamide, $10 \mathrm{mmol} / \mathrm{L}$ EDTA, $0.5 \%$ bromorphenol blue, $0.5 \%$ xylene cyanol, $\mathrm{pH} 8.3$ ), and then $6 \mu \mathrm{l}$ of the mixture for each sample was separated on $1.5 \%$ agarose gel containing $0.5 \mu \mathrm{g} / \mathrm{ml}$ ethidium bromide, and photographed on gel imaging system (BioRad Cor. Ltd.).

\subsection{Data Analysis}

The photographic plates were scanned and analyzed using an computer-assisted image analysis system. The presence and absence of amplified bands were scored, and microbial community diversity of soil samples was measured by the percentage of polymorphic bands. Furthermore, POPGENE Version 1.32 program was employed to calculate Shannon's information index (I) and Nei's gene diversity $(\mathrm{H})$. Similarity coefficients were calculated by NTSYSpc Version 2.10 software [16], unweighted pair group method [17] and the SHAN (sequential, hierarchical agglomerative and nested clustering) routine was used to assess the association among soils in clustering dendrogram.

\section{RESULTS}

\subsection{Genetic Diversity of Soils Sampled from Huangni}

For soils sampled from Huangni village, in total, 359 reliable RAPD fragments were generated by 24 primers. In average, 14.96 bands were amplified by each RAPD primer. Among them, 324 (90.3\%) bands were polymorphic, and in average, 13.5 polymorphic bands were amplified by each primer. Statistical results showed that, bands amplified by each primer were varied from 7 to 24 , and polymorphic ratio for each primer was varied from $64.7 \%$ to $100 \%$ (Table 3). Nei's gene diversity index $(\mathrm{H})$ showed that, soil sample $2+3 \mathrm{~N}-\mathrm{H}-\mathrm{G}$ has the highest gene diversity (0.3836), and $3+1 \mathrm{R}-\mathrm{H}-\mathrm{G}$ the lowest (0.2373). Soil sample $2+3 \mathrm{~N}-\mathrm{H}-\mathrm{G}$ has the highest $(0.5718)$ ShannonWeaver index (I), and $3+1 \mathrm{R}-\mathrm{H}-\mathrm{G}$ the lowest $(0.4005)$ (Table 4). And expect for soil samples (2R-H-Q and $2 \mathrm{~N}-$ H-Q) that growing 2-years P. ginseng, the Nei's diversity index $(\mathrm{H})$ and the Shannon index (I) of rhizosphere soil were lower than non-rhizosphere soil for other soil samples.

Table 3. Amplifying results of RAPD primers on microbial DNA extracted from soils sampled from Huangni and Dafang.

\begin{tabular}{|c|c|c|c|c|c|c|c|c|}
\hline \multirow{2}{*}{ Primers } & \multicolumn{4}{|c|}{ Huangni } & \multicolumn{4}{|c|}{ Dafang } \\
\hline & $\mathrm{AF}$ & NPF & $\mathrm{PF}$ & RP (\%) & $\mathrm{AF}$ & NPF & $\mathrm{PF}$ & $\mathrm{RP}(\%)$ \\
\hline OPH8 & 11 & 0 & 11 & 100.0 & - & - & - & - \\
\hline OPH10 & 10 & 2 & 8 & 80.0 & - & - & - & - \\
\hline OPH11 & 16 & 0 & 16 & 100.0 & 10 & 3 & 7 & 70.0 \\
\hline OPI4 & 22 & 1 & 21 & 95.5 & 16 & 6 & 10 & 62.5 \\
\hline OPJ1 & 24 & 1 & 23 & 95.8 & 14 & 5 & 9 & 64.3 \\
\hline OPJ4 & 21 & 1 & 20 & 95.2 & 5 & 3 & 2 & 40.0 \\
\hline OPJ7 & 16 & 0 & 16 & 100.0 & 9 & 2 & 7 & 77.8 \\
\hline OPJ8 & 18 & 0 & 18 & 100.0 & - & - & - & - \\
\hline OPR7 & 13 & 0 & 13 & 100.0 & 8 & 1 & 7 & 87.5 \\
\hline OPR8 & 7 & 0 & 7 & 100.0 & 4 & 1 & 3 & 75.0 \\
\hline OPR9 & 15 & 0 & 15 & 100.0 & 7 & 3 & 4 & 57.1 \\
\hline OPR10 & 15 & 1 & 14 & 93.3 & 12 & 2 & 10 & 83.3 \\
\hline OPR11 & 16 & 4 & 12 & 75.0 & 11 & 4 & 7 & 63.6 \\
\hline OPR14 & 15 & 3 & 12 & 80.0 & 11 & 3 & 8 & 72.7 \\
\hline OPR16 & 14 & 4 & 10 & 71.4 & - & - & - & - \\
\hline OPR17 & 17 & 6 & 11 & 64.7 & 13 & 7 & 6 & 46.1 \\
\hline OPR19 & 16 & 2 & 14 & 87.5 & - & - & - & - \\
\hline OPS4 & 17 & 2 & 15 & 88.2 & 15 & 2 & 13 & 86.7 \\
\hline OPS6 & 15 & 0 & 15 & 100.0 & - & - & - & - \\
\hline OPS10 & 15 & 1 & 14 & 93.3 & 11 & 7 & 4 & 36.4 \\
\hline OPT16 & 11 & 2 & 9 & 81.8 & 11 & 0 & 11 & 100.0 \\
\hline OPT17 & 13 & 1 & 12 & 92.3 & 13 & 5 & 8 & 61.5 \\
\hline OPT18 & 10 & 1 & 9 & 90.0 & 11 & 4 & 7 & 72.7 \\
\hline OPT19 & 12 & 3 & 9 & 75.0 & - & - & - & - \\
\hline Total & 359 & 35 & 324 & 90.3 & 181 & 58 & 123 & 68.0 \\
\hline
\end{tabular}

Note: "AF" indicates fragments amplified; "NPF" indicates non-polymorphic fragments; "PF" indicates polymorphic fragments; "RP" indicates ratio of polymorphism. 
Table 4. Nei's gene diversity and Shannon's information index of microbial community at DNA level in soils sampled from Huangni and Dafang.

\begin{tabular}{|c|c|c|c|c|}
\hline \multirow{2}{*}{ Soil samples } & \multicolumn{2}{|c|}{ Huangni } & \multicolumn{2}{|c|}{ Dafang } \\
\hline & $\mathrm{H}$ & I & $\mathrm{H}$ & I \\
\hline $1 \mathrm{R}-/ 1 \mathrm{~N}-\mathrm{H}(\mathrm{D})-\mathrm{G}$ & $0.2900 / 0.3323$ & $0.4652 / 0.5145$ & $0.3538 / 0.2869$ & $0.5388 / 0.4616$ \\
\hline 2R-/2N-D-G & - & - & $0.3244 / 0.2740$ & $0.5054 / 0.4460$ \\
\hline 3R-/3N-H(D)-G & $0.3735 / 0.3776$ & $0.5606 / 0.5651$ & $0.3059 / 0.2059$ & $0.4840 / 0.3600$ \\
\hline $2+2 \mathrm{R}-/ 2+2 \mathrm{~N}-\mathrm{D}-\mathrm{G}$ & - & - & $0.3059 / 0.4070$ & $0.4840 / 0.5970$ \\
\hline $3+1 \mathrm{R}-/ 3+1 \mathrm{~N}-\mathrm{H}-\mathrm{G}$ & $0.2373 / 0.2678$ & $0.4005 / 0.4385$ & - & - \\
\hline $2+3 \mathrm{R}-/ 2+3 \mathrm{~N}-\mathrm{H}-\mathrm{G}$ & $0.3345 / 0.3836$ & $0.5171 / 0.5718$ & - & - \\
\hline $3+2 \mathrm{R}-/ 3+2 \mathrm{~N}-\mathrm{D}-\mathrm{G}$ & - & - & $0.1917 / 0.3538$ & $0.3410 / 0.5388$ \\
\hline $3+3 \mathrm{R}-/ 3+3 \mathrm{~N}-\mathrm{H}(\mathrm{D})-\mathrm{G}$ & $0.3092 / 0.3630$ & $0.4878 / 0.5491$ & $0.2997 / 0.3480$ & $0.4767 / 0.5324$ \\
\hline $3 \mathrm{R}-/ 3 \mathrm{~N}-\mathrm{H}-\mathrm{Q}$ & $0.3544 / 0.3609$ & $0.5395 / 0.5467$ & - & - \\
\hline 2R-/2N-H-Q & $0.3300 / 0.3185$ & $0.5119 / 0.4987$ & - & - \\
\hline $1+2 \mathrm{R}-/ 1+2 \mathrm{~N}-\mathrm{D}-\mathrm{Q}$ & - & - & $0.3244 / 0.3121$ & $0.5054 / 0.4913$ \\
\hline $1+3 \mathrm{R}-/ 1+3 \mathrm{~N}-\mathrm{H}-\mathrm{Q}$ & $0.3185 / 0.3479$ & $0.4987 / 0.5322$ & - & - \\
\hline
\end{tabular}

Through "0" and "1" matrix analysis by NTSYS, dendrogram were drew base on coefficients of polymorphic DNA bands (Figure 1). Results showed that, coefficient of DNA bands similarity between $3+1 \mathrm{R}-\mathrm{H}-\mathrm{G}$ and $2+3 \mathrm{~N}-\mathrm{H}-\mathrm{G}$ was the lowest $(0.5278)$, and the highest $(0.8457)$ between $3+1 \mathrm{R}-\mathrm{H}-\mathrm{G}$ and $3+1 \mathrm{~N}-\mathrm{H}-\mathrm{G}$. Clustering results showed that, no matter $P$. gensing or $P$. quinquefolius, at the first 1 to 3 years, microbial communities between rhizosphere and non-rhizosphere soils have no significant change. For example, $1 \mathrm{R}-\mathrm{H}-\mathrm{G}$ to $1 \mathrm{~N}-\mathrm{H}-\mathrm{G}$, $2 \mathrm{R}-\mathrm{H}-\mathrm{Q}$ to $2 \mathrm{~N}-\mathrm{H}-\mathrm{Q}, 3 \mathrm{R}-\mathrm{H}-\mathrm{G}$ to $3 \mathrm{~N}-\mathrm{H}-\mathrm{G}$ and $3 \mathrm{R}-\mathrm{H}-\mathrm{Q}$ to $3 \mathrm{~N}-\mathrm{H}-\mathrm{Q}$. Though $3+1 \mathrm{R}-\mathrm{H}-\mathrm{G}$ and $3+1 \mathrm{~N}-\mathrm{H}-\mathrm{G}$ were $4-$ years soils, which were transplanted to the new growing environment no more than one year, microbial communities showing no marked difference between rhizosphere and non-rhizosphere soils. Clustering results also showed that, no matter 4 to 6 years $P$. gensing or $P$. quinquefolius, for example, soil samples $2+3 \mathrm{R}-\mathrm{H}-\mathrm{G}$ to 2 $+3 \mathrm{~N}-\mathrm{H}-\mathrm{G}, 3+3 \mathrm{R}-\mathrm{H}-\mathrm{G}$ to $3+3 \mathrm{~N}-\mathrm{H}-\mathrm{G}, 1+3 \mathrm{R}-\mathrm{H}-\mathrm{Q}$ to 1 $+3 \mathrm{~N}-\mathrm{H}-\mathrm{Q}$ has transplanted from one place to another growing area for a long time (about three years); In addition, the influence of root exudates on rhizosphere microbial community was increasing with the grows of $P$. ginseng roots, and microbial communities showed distinct change between rhizosphere and non-rhizosphere soils.

\subsection{Genetic Diversity of Soils Sampled from Dafang}

For soils sampled from Dafang village, in total, 17 primers generated 181 reliable RAPD fragments, in average, 10.65 bands were amplified by each RAPD primer. Among them, $123(68.0 \%)$ were polymorphic bands, 7.24 polymorphic bands were amplified by each primer in average. The number of bands amplified by each primer varied from 5 to 16 . The polymorphic ratio in each primer varied from $36.4 \%$ to $100 \%$ (Table 3). Results showed that, Nei's gene diversity index $(\mathrm{H})$ of soil sample $2+2 \mathrm{~N}-\mathrm{D}-\mathrm{G}$ was the highest (0.4070), and $3+2 \mathrm{R}-\mathrm{D}-\mathrm{G}$ the lowest (0.1917). Shannon-Weaver index of soil sample $2+$ $2 \mathrm{~N}-\mathrm{D}-\mathrm{G}$ was the highest $(0.5970)$, and $3+2 \mathrm{R}-\mathrm{D}-\mathrm{G}$ the lowest (0.3410) (Table 4). Except for soil samples (1RN-D-G and 1N-D-G, 2R-D-G and 2N-D-G, 3R-D-G and $3 \mathrm{~N}-\mathrm{D}-\mathrm{G}, 1+2 \mathrm{R}-\mathrm{D}-\mathrm{G}$ and $1+2 \mathrm{~N}-\mathrm{D}-\mathrm{G})$ that growing 1 to 3 ages of $P$. ginseng, the Nei's diversity index $(\mathrm{H})$ and the Shannon index (I) of rhizosphere soil were lower than non-rhizosphere soil for other soil samples.

Dendrogram drew based on coefficient of DNA band similarity indicated differences between soil samples at DNA level (Figure 2). Results showed that, Coefficient of DNA band similarity between 1 R-D-G and $2+2 \mathrm{R}-$ $\mathrm{D}-\mathrm{G}$ was the lowest (0.4762), and the highest (0.8730) between $1+2 \mathrm{R}-\mathrm{D}-\mathrm{Q}$ and $1+2 \mathrm{~N}-\mathrm{D}-\mathrm{Q}$. Clustering results of $P$. gensing soils $1 \mathrm{R}-\mathrm{D}-\mathrm{G}$ to $1 \mathrm{~N}-\mathrm{D}-\mathrm{G}, 2 \mathrm{R}-\mathrm{D}-\mathrm{G}$ to $2 \mathrm{~N}-$ D-G showed that, in the first 1 to 2 years, no matter $P$. gensing or $P$. quinquefolius, microbial communities in rhizosphere and non-rhizosphere soil have no significant difference, and the same for soil samples $1+2 \mathrm{R}-\mathrm{D}-\mathrm{Q}$ to $1+2 \mathrm{~N}-\mathrm{D}-\mathrm{Q}$, which were the 1-year ginseng transplanted to a new growing environment no more than two years. Clustering results of soil samples $2+2 \mathrm{R}-\mathrm{D}-\mathrm{G}$ to $2+$ $2 \mathrm{~N}-\mathrm{D}-\mathrm{G}, 3+2 \mathrm{R}-\mathrm{D}-\mathrm{G}$ to $3+2 \mathrm{~N}-\mathrm{D}-\mathrm{G}, 3+3 \mathrm{R}-\mathrm{D}-\mathrm{Q}$ to $3+$ $3 \mathrm{~N}-\mathrm{D}-\mathrm{Q}$ showed that, there are significant differences on microbial communities of 4 to 6 years $P$. ginseng rhizosphere and non-rhizosphere soil samples.

\section{DISCUSSION}

In this study, two hundred RAPD primers were prepared for this experiment, but only a small part of them can amplifying clearly and highly polymorphic fragments were used to reveal the influence of mono-cropping of $P$. ginseng on soil microbial community diversity. Results suggested that, there is significant difference on microbial community between soils sampled from Huangni and Dafang, because the number of amplified bands presents 


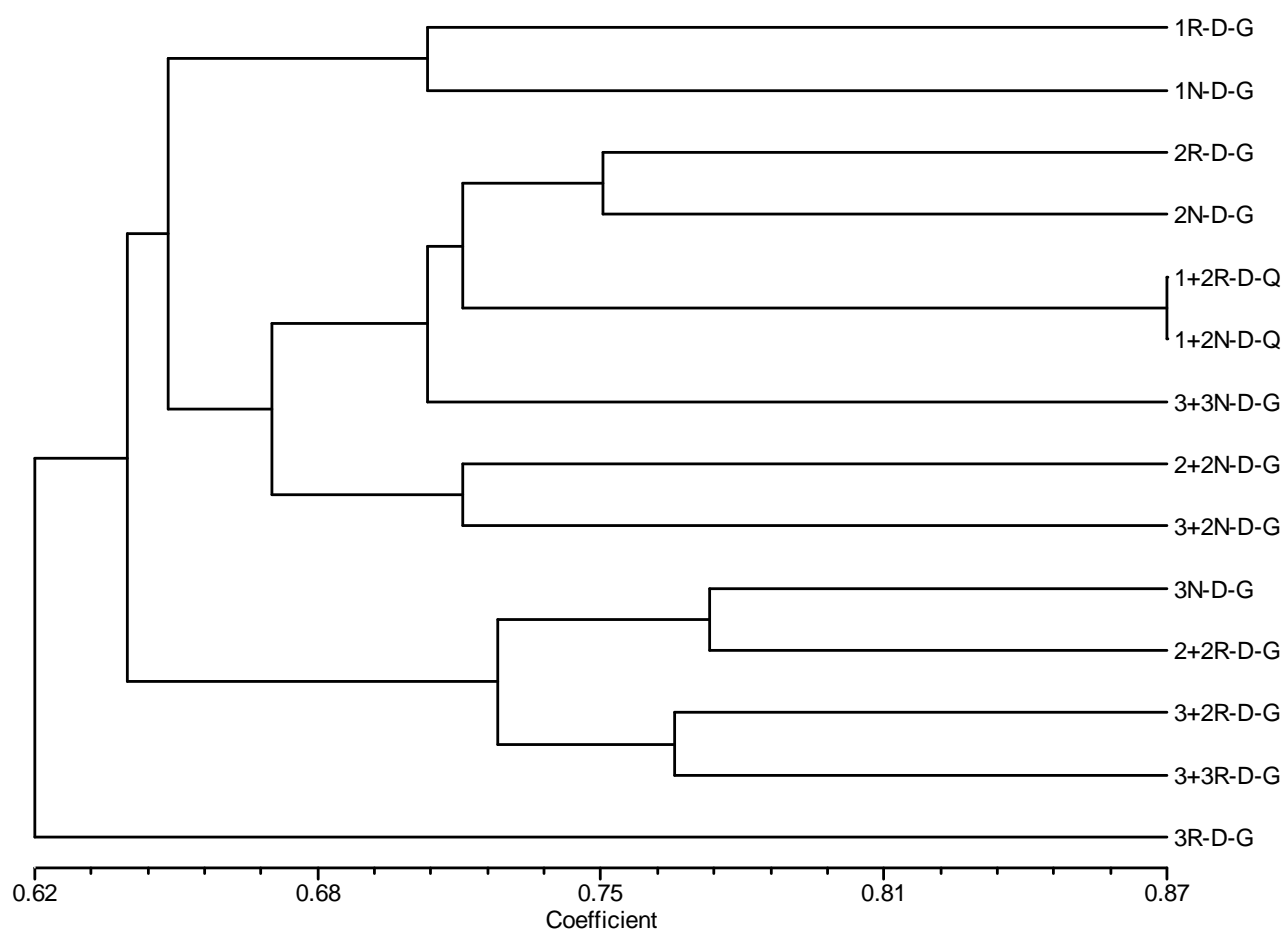

Figure 2. Dendrogram of rhizosphere and non-rhizosphere soils of $P$. ginseng from Dafang village.

marked difference at two sampling sites. The Nei's diversity index $(\mathrm{H})$ and Shannon index (I) also indicated that, except for some exceptions, the microbial community diversity of rhizosphere soil was lower than non-rhizosphere soil. Dendrogram results suggested that, difference on microbial community between rhizosphere and nonrhizposhere soil of low age ( 1 to 3 years) $P$. ginseng were not significant, which was on the contrary for higher age (4 to 6 years) $P$. ginseng. Plants supply resources for soil communities by providing organic matter through leaf-litter inputs, through the release of root exudates, or through other ways of deposition of organic compounds into the soil environment, and as a result, specific soil communities form under different plant species $[18,19]$. So we deduced that, as the primary carbon source for the sustentation of soil microbial community, root exudates have directional selection press on microbial species growing in the soil environment, and finally resulted in the degradation of microbial communities.

Usually, rotation provides a greater concentration and diversity of organic materials than the mono-cultural systems, which can improve microbial community diversity and stabilized microclimate to perform their function $[20,21]$. The RAPD analysis demonstrated that there is significant diversity on not only microbial communities between rhizosphere and non-rhizosphere soils of $P$. ginseng or $P$. quinquefolius, but also plants with different ages. Furthermore, Nei's gene diversity and Shannon's information index in soils were influenced by mono-cropping significantly. In this present, the difference on microbial community diversity is increasing with the growing years of $P$. ginseng at a given site. And, the influence was more notable for 4 to 6 years ginseng. Result demonstrated that, mono-cropping systems have negative effects on soil microbial communities, and with the growing of $P$. ginseng root, the influence tend to be more and more marked. On one hand, mono cultivation systems decrease given organic matter which is benefit to soil microorganisms, and made diversity of microbial community decrease. On the other hand, the environmental factors, such as overuse of nitrogen, phosphorus fertilizers, germicide and pesticides, exudates released from root to their adjacent soil may induce changes of soil microbial community and soil physic-chemical properties, also [13,22].

Historically, the research on biodiversity was mainly concentrated on plants and animals, despite microorganisms being the critical components in the soil ecosystems, microbial diversity was regarded as an indicator of soil quality, and study on their diversities was hampered due to the difficulties in measuring. Since no more than $10 \%$ soil microorganisms have been isolated and studied yet [23]. Furthermore, the spatial distribution and interaction may have influence on the quantitative and representative of microorganisms in soil [24]. Molecular methods are emerging as tools to better study microbial communities in soils [25]. The difference among microbial species is essentially represented in their genetic diversity at DNA sequence. Thus, soil microbial community diversity can be studied by using molecular techniques at DNA level. 
RAPD markers require no genomic structure information on the materials studied, and the binding sites of which are randomly distributed on the genome DNA; furthermore, it is easy-operating, economic, effective and yields a great deal of information to discover small variations between similar genomes [10,26,27], all these made the RAPD technique an popular DNA-based method for assessing soil microbial community. In this study, RAPD technique revealed the influence of continuous $P$. ginseng cultivation on soil microbial community diversity. The results may suggest that the change in microbial community DNA composition was accompanied with the change in microbial functional properties.

However, the same as other DNA-based techniques, such as DGGE, ARISA, T-RFLP, etc., RAPD technique also has its limitation for determining soil microbial community. As that RAPD primers only 10 oligonucleotide bases, many factors involved in the amplification could affect the reproducibility and instability of RAPD results $[28,29]$, and which made the repeatability of RAPD not as perfect as other PCR-based methods. In order to determine the most suitable RAPD conditions, concentration and proportion of $\mathrm{Mg}^{2+}, \mathrm{dNTP}$, template DNA and primer, annealing temperature and extending time were evaluated. Another problem worth attention is that, as other PCR-based methods, RAPD amplification was also sensitive to the concentration of DNA templates, only those more than $1 \%$ of total DNA can be detected by this method [30]. Although the effects of PCR bias, RAPD method was still used in genetic diversity research [31,32]. However, as the enormous of microorganisms and the limited resolving ability of RAPD, it is necessary to integrate diverse approaches and perspectives to understand more precisely the changes in the diversity of microbial communities [33,34].

\section{ACKNOWLEDGEMENTS}

The authors thank Mr. H. M. Fang and Mr. Q. Y. Gao for assistance collecting soil samples. The work was supported by a grant from the National Natural Science Foundation of China (81072992) and Doctoral Fund of Ministry of Education of China (200800231060).

\section{REFERENCES}

[1] Jung, J.D., Park, H.W., Hahn, Y., Hur, C.G., In, D.S., Chung, H.J., Liu, J.R. and Choi, D.W. (2003) Discovery of genes for ginsenoside biosynthesis by analysis of ginseng expressed sequence tags. Plant Cell Report, 22, 224230. doi:10.1007/s00299-003-0678-6

[2] Yang, L.M., Chen, C.B., Wang, X.Q., Zhang, L.X. and Tian, Y.X. (2004) Ecological restoration and reused modes of old ginseng land in the Changbai mountainous area and its existing problems. Journal of Jilin Agricutural University, 26, 546-549, 553.

[3] Wu, L.J., Zhao, Y.H., Guan, Y.M. and Peng, S.F. (2008)
A review on studies of the reason and control methods of succession cropping obstacle of Panax ginseng C.A. Mey. Special Wild Economic Animal Plant Research, 2, 68-72.

[4] Jin, H., Yu, S.L. and Cao, Z.Q. (2006) Improvement of long-cultivated land of ginseng and farmland for continuous cultivation of ginseng and quinquefolium. Modernization of Traditional Chinese Medicine and Materia Medica-World Science and Technology, 8, 84-87.

[5] Bais, H.P., Weir, T.L., Perry, L.G., Gilroy, S. and Vivanco, J.M. (2006) The role of root exudates in rhizosphere interactions with plants and other organisms. Annual Review of Plant Biology, 57, 233-266. doi:10.1146/annurev.arplant.57.032905.105159

[6] Bertin, C., Yang, X.H. and Weston, L.A. (2003) The role of root exudates and allelochemicals in the rhizosphere. Plant Soil, 256, 67-83. doi:10.1023/A:1026290508166

[7] Castro, H.F., Classen, A.T., Austin, E.E., Norby, R.J. and Schadt, C.W. (2010) Soil microbial community responses to multiple experimental climate change drivers. Applied and Environmental Microbiology, 76, 999-1007. doi:10.1128/AEM.02874-09

[8] Hjort, K., Lembke, A., Speksnijder, A., Smalla, K. and Jansson, J.K. (2007) Community structure of actively growing bacterial populations in plant pathogen suppressive soil. Microbial Ecology, 53, 399-413. doi:10.1007/s00248-006-9120-2

[9] Shasany, A.K., Darokar, M.P., Dhawan, S., Gputa, A.K., Gputa, S., Shukla, A.K., Patra, N.K. and Khanuja, S.P.S. (2005) Use of RAPD and AFLP markers to identify interand intraspecific hybrids of mentha. Journal of Heredity, 96, 542-549. doi:10.1093/jhered/esi091

[10] Premanandh, J., Priya, B., Prabaharan, D. and Uma, L. (2009) Genetic heterogeneity of the marine cyanobacterium Leptolyngbya valderiana (Pseudana baenaceae) evidenced by RAPD molecular markers and 16S rDNA sequence data. Journal of Plankton Research, 31, 11411150. doi:10.1093/plankt/fbp055

[11] Solla, A., Dacasa, M.C., Nasmith, C., Hubbes, M. and Gil, L. (2008) Analysis of Spanish populations of Ophiostoma ulmi and O. novo-ulmi using phenotypic characteristics and RAPD markers. Plant Pathology, 57, 33-44.

[12] Yang, Y.H., Yao, J., Hu, S. and Qi, Y. (2000) Effects of agricultural chemicals on DNA sequence diversity of soil microbial community: A study with RAPD marker. Microbial Ecology, 39, 72-79. doi:10.1007/s002489900180

[13] Yao, H.Y., Jiao, X.D. and Wu, F.Z. (2006) Effects of continuous cucumber cropping and alternative rotations under protected cultivation on soil microbial community diversity. Plant Soil, 284, 195-203. doi:10.1007/s11104-006-0023-2

[14] Li, Y., Huang, X.F., Ding, W.L. and Zhang, R. (2008) Allelopathic effects of soil extracts on the growth of ginseng seeds and its chemical composition. Ecology and Environment, 17, 1173-1178.

[15] Li, Y., Liu, S.L., Huang, X.F. and Ding, W.L. (2009) Allelopathy of ginseng root exudates on pathogens of ginseng. Acta Ecologica Sinica, 29, 161-168.

[16] Rohlf, F.J. (1994) NTSYS-pc, Numerical taxonomy and 
multivariate analysis system, version 1.80. Exeter Software, New York

[17] Sneath, P.H.A. and Sokal, R.R. (1973) Numerical taxonomy: The principles and practice of numerical classification. Freeman, San Francisco, 573.

[18] Wolfe, B.E. and Klironomos, J.N. (2005) Breaking new ground: Soil communities and exotic plant invasion. Bioscience, 55, 477-487. doi:10.1641/0006-3568(2005)055[0477:BNGSCA]2.0.C $\underline{\mathrm{O} ; 2}$

[19] Pivato, B., Mazurier, S., Lemanceau, P., Siblot, S., Berta, G., Mougel, C. and van Tuinen, D. (2007) Medicago species affect the community of arbuscular mycorrhizal fungi associated with roots. New Phytology, 176, 197210. doi:10.1111/j.1469-8137.2007.02151.x

[20] Klose, S. and Tabatabai, M.A. (2000) Urease activity of microbial biomass in soils as affected by cropping systems. Biology and Fertility of Soils, 31, 191-199. doi:10.1007/s003740050645

[21] Lupwayi, N.Z., Rice, W.A. and Clayton, G.W. (1998) Soil microbial diversity and community structure under wheat as influenced by tillage and crop rotation. Soil Biology \& Biochemistry, 30, 1733-1741. doi:10.1016/S0038-0717(98)00025-X

[22] Lin, X.G., Yin, R., Zhang, H.Y., Huang, J.F., Chen, R.R. and Cao, Z.H. (2004) Changes of soil microbiological properties caused by land use changing from rice-wheat rotation to vegetable cultivation. Environmental Geochemistry and Health, 26, 119-128. doi:10.1023/B:EGAH.0000039574.99651.65

[23] Garbeva, P., van Veen, J.A. and van Elsas, J.D. (2004) Microbial diversity in soil: Selection of microbial populations by plant and soil type and implications for disease suppressiveness. Annual Review of Phytopathology, 42, 243-270. doi:10.1146/annurev.phyto.42.012604.135455

[24] Hartmann, M. and Widmer, F. (2006) Community structure analysis are more sensitive to differences in soil bacterial communities than anonymous diversity indices. Applied and Environmental Microbiology, 72, 7804-7812. doi:10.1128/AEM.01464-06

[25] Schutter, M.E., Sandeno, J.M. and Dick, R.P. (2001) Seasonal, soil type, alternative management influences on microbial communities of vegetable cropping systems. Biology and Fertility of Soils, 34, 397-410. doi:10.1007/s00374-001-0423-7

[26] Sharma, N., Sudarsan, Y., Sharma, R. and Singh, G. (2008) RAPD analysis of soil microbial diversity in western Rajasthan. Current Science India, 94, 1058-1061.

[27] Xie, B. and Xu, Y.T. (2003) The effect of $\mathrm{Zn}$ ions on activated sludge microbes and its DNA sequence diversity analysis. Environmental Science \& Rearch, 16, 1831.

[28] Tcherneva, E., Rijpens, N., Jersek, B. and Herman, L.M. (2000) Differentiation of Brucella species by random amplified polymorphic DNA analysis. Journal of Applied Microbiology, 88, 69-80. doi:10.1046/j.1365-2672.2000.00945.x

[29] Tyler, K.D., Wang, G., Tyler, S.D. and Johnson, W.M. (1997) Factors affecting reliability and reproducibility of amplification based DNA fingerprinting of representative bacterial pathogens. Journal of Clinical Microbiology, 35, 339-346

[30] Xia, X., Bollinger, J. and Ogram, A. (1995) Molecular genetic analysis of the response of three soil microbial communities to the application of 2,4-D. Molecular Ecology, 4, 17-28. doi:10.1111/j.1365-294X.1995.tb00188.x

[31] Winget, D.M. and Wommack, K.E. (2008) Randomly amplified polymorphic DNA PCR as a tool for assessment of marine viral richness. Applied and Environmental Microbiology, 74, 2612-2618. doi:10.1128/AEM.02829-07

[32] Helton, R.R. and Wommack, K.E. (2009) Seasonal dynamics and metagenomic characterization of estuarine viriobenthos assemblages by randomly amplified polymorphic DNA PCR. Applied and Environmental Microbiology, 75, 2259-2265. doi:10.1128/AEM.02551-08

[33] Nannipieri, P., Ascher, J., Ceccherini, M.T., Landi, L. Pietramellara, G. and Renella, G. (2003) Microbial diversity and soil functions. European Journal of Soil Science, 54, 655-670. doi:10.1046/j.1351-0754.2003.0556.x

[34] Rajasundari, K., Ilamurugu, K. and Logeshwaran, P. (2009) Genetic diversity in rhizobial isolates determined by RAPDs. African Journal of Biotechnology, 8, 2677-2681. 